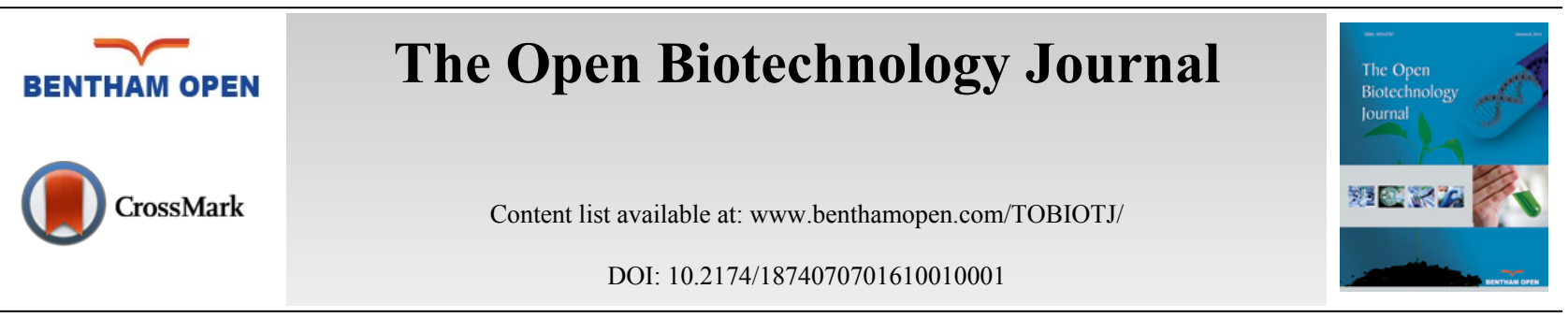

\title{
Multi-Fixed-Bed Bioreactor System Applied for Bioprocess Development of Immobilized Lactic Acid Bacteria
}

\author{
Rebecca Faschian*, Sonakshi De and Ralf Pörtner \\ Hamburg University of Technology, Institute of Bioprocess and Biosystems Engineering, Denickestr. 15, D-21073 \\ Hamburg, Germany
}

\begin{abstract}
The multi-fixed-bed bioreactor "Multiferm" provides a downscaled system for the development of fixed-bed processes with immobilized microorganisms or cells. It consists of twelve single fixed-bed units that can be operated independently. Different bacterial strains, carriers used for immobilization, media or flow rates can be studied in one compact experimental set-up. Experiments can be run in parallel to allow for determination of experimental errors. In these studies several continuous cultivations were carried out with Lactobacillus delbrueckii ssp. bulgaricus using different dilution rates and culture durations as proof-ofconcept for the Multiferm. Parameters relevant for process design such as reproducibility of simultaneously performed cultures, optimal dilution rate and long-term performance were determined by means of volume specific lactate and biomass productivity. First indications on a reduced growth rate of the cells due to immobilization were found.
\end{abstract}

Keywords: Cell density, continuous cultivation, dilution rate, experimental error, fixed-bed, lactic acid bacteria, metabolic activity, process development, scale-down.

\section{INTRODUCTION}

The main advantage of the cultivation of bacteria in fixed-bed bioreactors is cell retention [1] but there are also other promising aspects like higher enzyme activity, higher $\mathrm{pH}$ and temperature stability [2] as well as higher plasmid stability and higher rate of correctly folded proteins [3 - 5] in recombinant bacterial strains. Fixed-bed reactor systems have a reduced system complexity, which reduces costs. The continuous operation or at least prolonged cultivation period due to higher stability increases productivity $[3,6-8]$.

There have been numerous reports on immobilized lactic acid bacteria (LAB) for production of lactic acid, starter cultures, bacteriocins (e.g. nisin) and aromatic compounds under high volumetric productivity compared to suspension cultivation $[3,5,9-13]$. One reason for this is the application of dilution rates that are several times higher than the maximum specific growth rate during exponential growth $[6,12,14]$. Nevertheless, the number of industrial fixed-bed processes is quite small because of the lack of process development tools for fixed-bed processes.

Regarding the previously mentioned advantages for fixed-bed reactors as well as the potential of lactic acid bacteria it is obvious that there is a requirement for a specific process development tool. Therefore, a downscaled, cost-efficient multiple fixed-bed reactor system was developed. This reactor system allows the fast generation of cultivation data because of its twelve single fixed-beds. By this, it is possible to use different bacterial strains, carriers, media or flow rates in one compact experimental setup. Furthermore, immobilization procedures and required time for stable running can be investigated in this system by stopping cultivation at different points of time.

The objective of the present study was to determine parameters relevant for design of fixed bed processes such as reproducibility, optimal dilution rate and long-term performance. Lactobacillus delbrueckii ssp. bulgaricus was used as model system.

* Address correspondence to this author at the Hamburg University of Technology, Institute of Bioprocess and Biosystems Engineering, Denickestr. 15, D-21073 Hamburg, Germany; Tel: +49 4042878 2886; Fax: +49 4042878 2909; Email: poertner@tuhh.de 


\section{MATERIALS AND METHODS}

\section{Multi-fixed-bed Bioreactor Multiferm}

The multiple bioreactor system Multiferm (medorex e.K., Nörten-Hardenberg, Germany) consists of twelve single fixed-bed units, each with a working volume of $10 \mathrm{~mL}$. All twelve are placed in a $1.5 \mathrm{~L}$ conditioning vessel (see Fig. 1). The fixed-bed units and the conditioning vessel are made of Duran glass, the lid and the connections consist of the autoclavable and resistant organic polymer polyether ether ketone (PEEK). Within a fixed-bed unit (see Fig. 2). The carriers are packed between two PEEK discs with equal perforations for uniform liquid distribution within the reactors. The liquid flows from bottom to top for easy release of process gasses. The Multiferm system is provided with temperature (between $5-60{ }^{\circ} \mathrm{C}$ ), $\mathrm{pH}$ (between 3 - 10) and aeration (between $0.1-1 \mathrm{~L} / \mathrm{h}$ ) controls. It is further equipped with pumps, which can dispense fluids with flow rates between $0.15-3 \mathrm{~mL} / \mathrm{min}$.

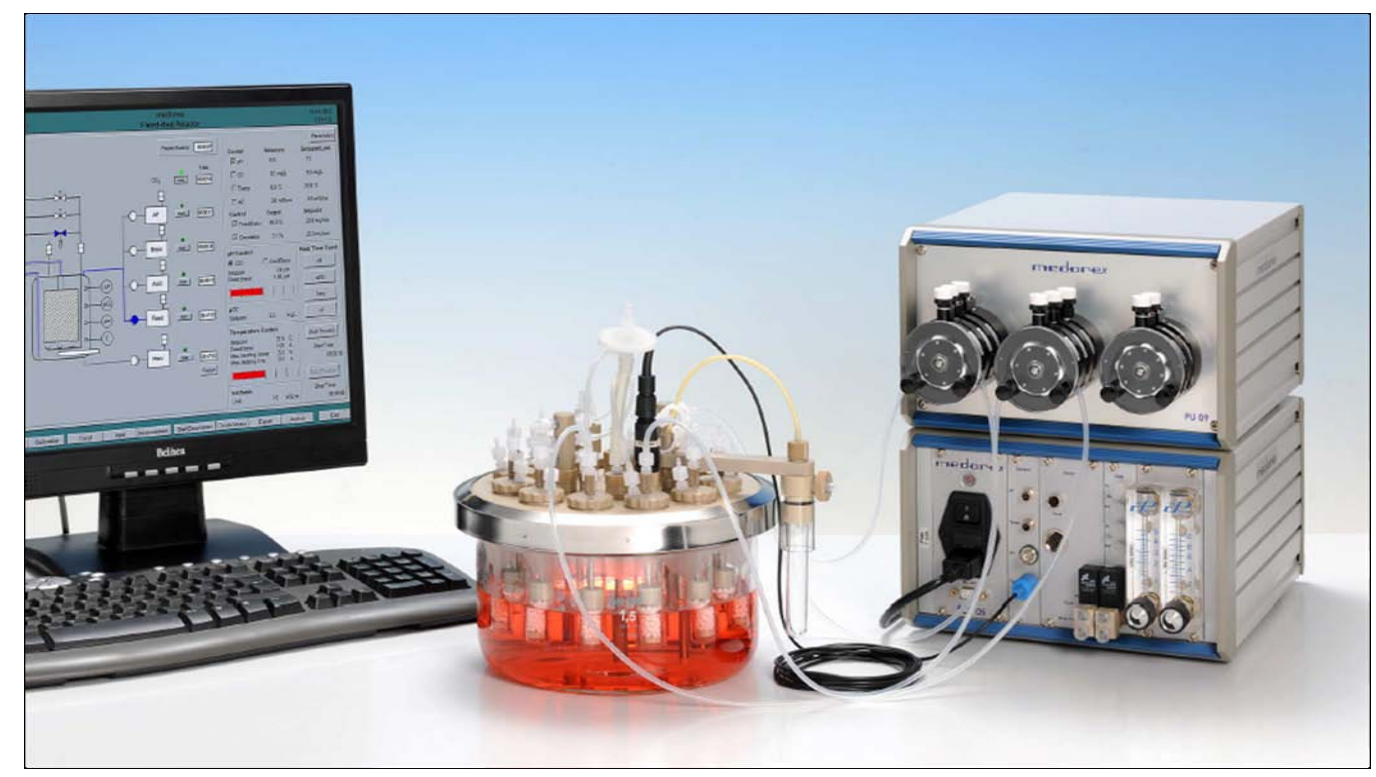

Fig. (1). The Multiferm multi-fixed-bed fermenter system. Middle: Conditioning vessel with the 12 single fixed-bed units. Left: Process control system WinErs. Right: Control unit for feed, harvest, pH, aeration and temperature (medorex e.k., with kind permission).

\section{Carrier Material}

For immobilization VitraPOR ${ }^{\circledR}$ carriers from Robu Glasfiltergeräte GmbH (Hattert, Germany) were used. They are made of sintered borosilicate glass and are therefore autoclavable and resistant against chemicals. VitraPOR ${ }^{\circledR}$ is spherical in shape with an average diameter of $4 \mathrm{~mm}$ (Fig. 3) and has a porosity of $36 \%$, while the inner surface is $0.13 \mathrm{~mm}^{2} / \mathrm{g}$.

\section{Bacterial Strain}

The experiments were performed with Lactobacillus delbrueckii ssp. bulgaricus (L. bulgaricus), which is an anaerobic, non-motile and non-spore forming lactic acid bacterium. Its growth conditions are: temperature $40-44{ }^{\circ} \mathrm{C}$, low $\mathrm{pH}$ from 4.6 to 6 , complex nutrition. This strain is obligatory homofermentative producing no $\mathrm{CO}_{2}$ but $\mathrm{D}$-lactate exclusively. Its maximum specific growth rate $\mu_{\max }$ in shaking flask cultivation $\left(40^{\circ} \mathrm{C}\right.$, Difco Lacto-bacilli MRS Broth with initial $\mathrm{pH}$ of 6 , data not shown here) was determined to be $0.391 / \mathrm{h}$ and it has $\mathrm{q}_{\text {Lac,batch }}=2.610^{-12} \mathrm{~g} /($ cells.h), which is the cell specific lactate production rate in batch suspension cultivation. For the latter, the produced lactate $\Delta \mathrm{c}_{\mathrm{Lac}}$. [g/L] was divided by the formed biomass $\Delta \mathrm{X}$ [cells/L] as well as the duration of the exponential phase $\Delta \mathrm{t}[\mathrm{h}]$.

\section{Cultivation}

All cultivations were carried out at a temperature of $40{ }^{\circ} \mathrm{C}$ using complex MRS medium containing $20 \mathrm{~g} / \mathrm{L}$ glucose with an initial $\mathrm{pH}$ of 6 . Within the fixed-bed the $\mathrm{pH}$ was not controlled. 


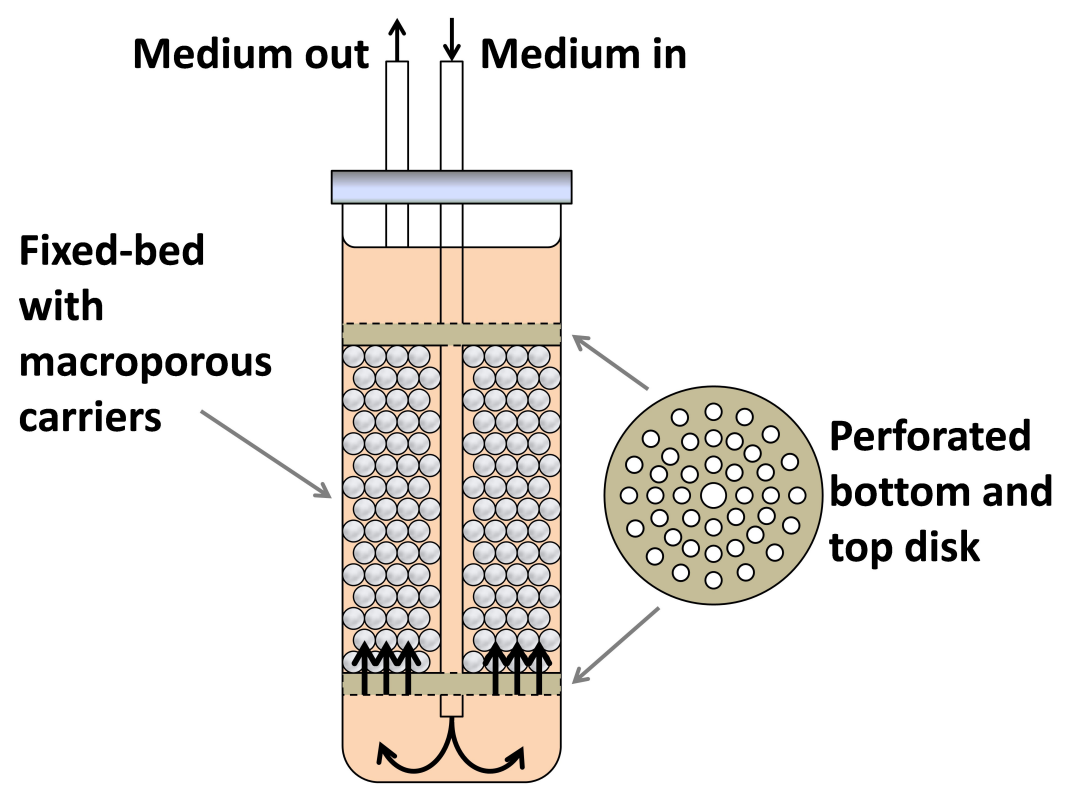

Fig. (2). Scheme of a fixed-bed unit.

\section{Preculture in Suspension}

For cultivation in the Multiferm a preculture has to be prepared. Therefore, a cryoculture of $1.5 \mathrm{~mL}$ containing $1 \cdot 10^{9}$ cells was incubated at $40^{\circ} \mathrm{C}$ for 14 to $16 \mathrm{~h}$ in $50 \mathrm{~mL}$ MRS medium. Then, fresh MRS medium was inoculated with $10 \%[\mathrm{v} / \mathrm{v}]$ inoculation volume of the preculture and incubated under same conditions until a cell density of $1 \cdot 10^{9}$ cells $/ \mathrm{mL}$ was reached. This second culture was centrifuged at $4,500 \cdot \mathrm{g}$. The cell pellet was resuspended in one fifth of the initial volume.
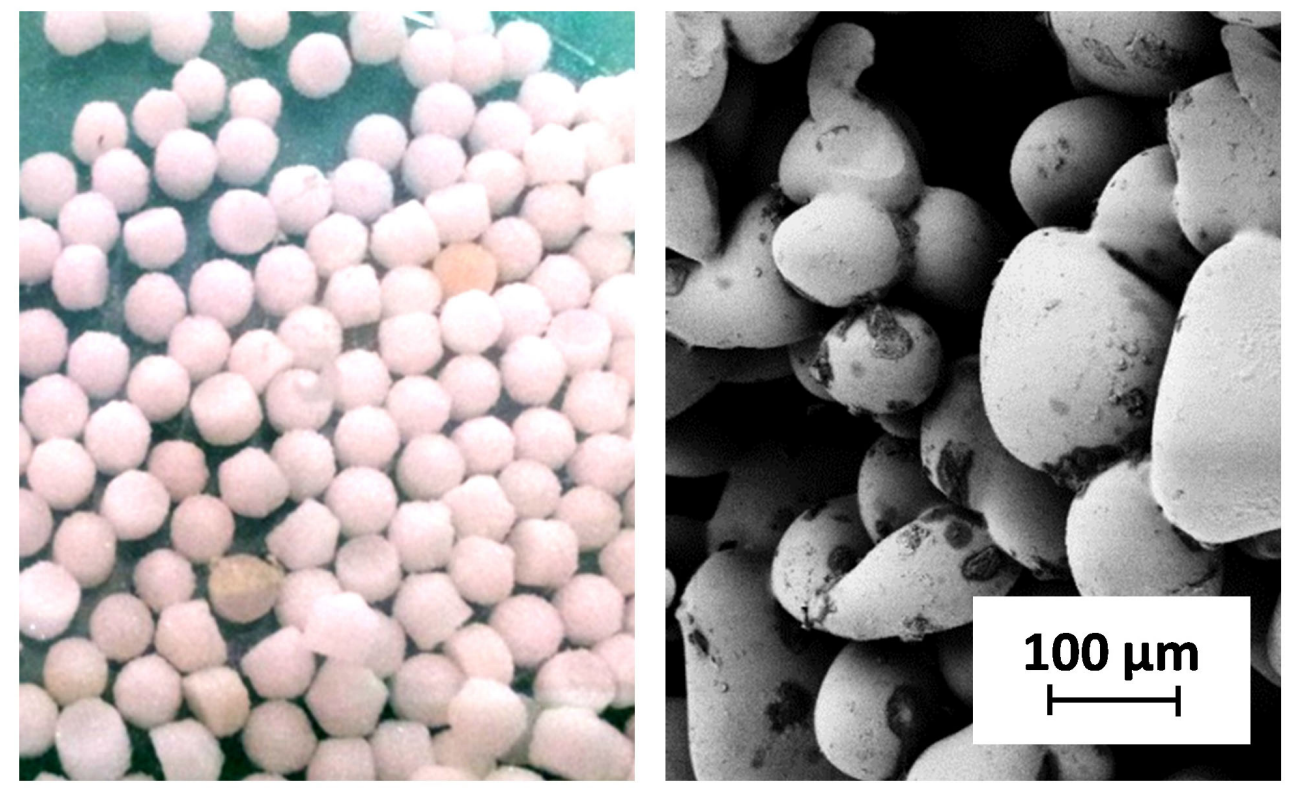

Fig. (3). Top: VitraPOR ${ }^{\circledR}$ carrier with a diameter of $4 \mathrm{~mm}$. Bottom: SEM image with 250 -fold magnitude (scale is $100 \mu \mathrm{m}$ ).

\section{Inoculation and Start up of Fixed-bed}

Each of the $10 \mathrm{~mL}$ fixed-bed reactors was filled with $10 \mathrm{~mL}$ of the cell suspension obtained as described in the previous section and incubated for $14 \mathrm{~h}$ at $40{ }^{\circ} \mathrm{C}$ to let the bacteria settle within the fixed-bed carriers. Afterwards, supernatant was removed and the perfusion was started with fresh medium using a dilution rate $\mathrm{D}$ of $0.67 \cdot \mu_{\max }(=$ $0.261 / \mathrm{h}$ ), which was increased after $24 \mathrm{~h}$. 
$\mathrm{Oh}$

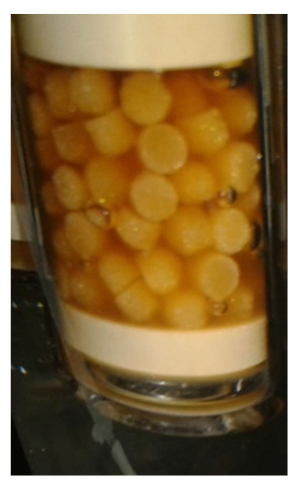

$48 \mathrm{~h}$

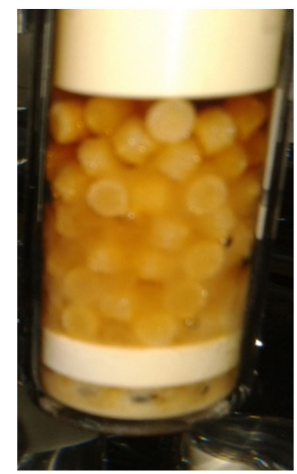

$80 \mathrm{~h}$

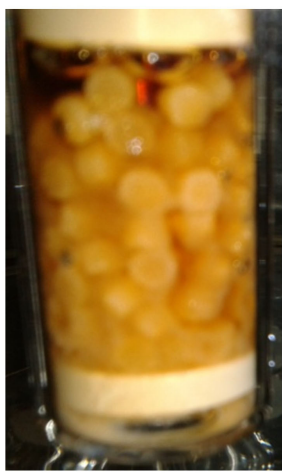

$120 \mathrm{~h}$

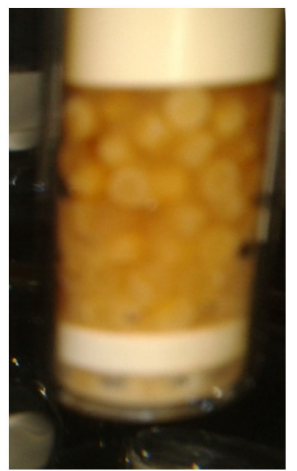

$154 \mathrm{~h}$

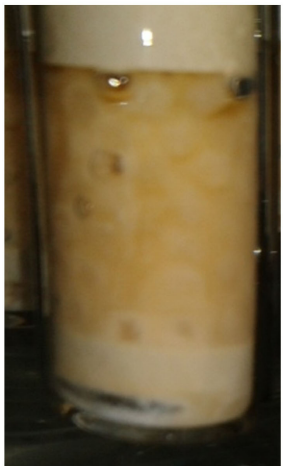

\section{process time}

Fig. (4). Carrier colonization during cultivation of L. bulgaricus in multi-fixed-bed fermenter system over $154 \mathrm{~h}$.

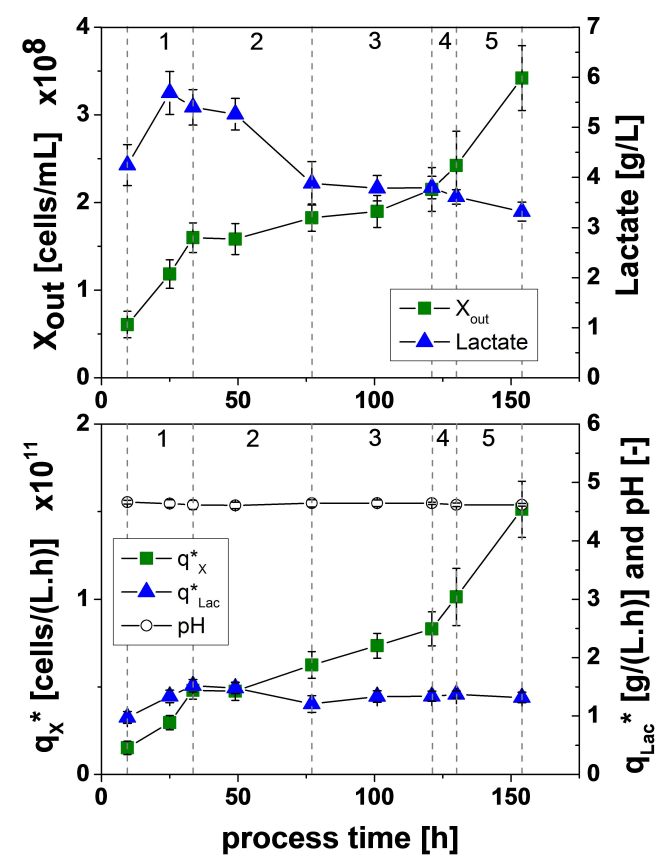

Fig. (5). Cultivation of L. bulgaricus in the Multiferm to test reproducibility of the system under different dilution rates (1: $\mathrm{D}=$ $\left.0.67 \cdot \mu_{\max }, 2: \mathrm{D}=0.75 \cdot \mu_{\max }, 3: \mathrm{D}=1.00 \cdot \mu_{\max }, 4: \mathrm{D}=1.10 \cdot \mu_{\max }, 5: \mathrm{D}=1.20 \cdot \mu_{\max }\right)$. Two times six fixed-bed units were run $(\mathrm{n}=12$ in total). Data points represent means \pm standard deviation. Conditions: MRS medium (initial $\mathrm{pH}$ of 6 ), $40{ }^{\circ} \mathrm{C}$.

\section{Analytics}

All samples were withdrawn from the inlet and the outlet flow of a fixed-bed unit and analyzed as described in the following on biomass, substrate (glucose) and product (lactate) concentrations. These concentrations were used to calculate volumetric productivities.

\section{Cell Density}

The growth of L. bulgaricus was monitored by measuring the optical density (OD) at a wave length of $600 \mathrm{~nm}$ with a spectrophotometer (V-1200, VWR International, Darmstadt, Germany) in polystyrene semi-micro cuvettes (Sarstedt, Nümbrecht, Germany). Additionally, bacteria were counted with a Neubauer improved hemocytometer with $0.02 \mathrm{~mm}$ depth to estimate the correction between OD and cell density $\mathrm{X}$ [cells/L] to be:

$$
X=O D \cdot 4 \cdot 10^{8} \quad[\mathrm{cells} / \mathrm{mL}]
$$




\section{Lactate and Glucose Concentration}

Samples were taken at the inlet and outlet of each fixed-bed unit to determine lactate and glucose concentration. This was done via HPLC (Kontron Instruments, Kontron HPLC 332 UV detector, RID-6A Shimadzu infrared detector, BioRad Aminex HPX-87H column, $5 \mathrm{mM} \mathrm{H}_{2} \mathrm{SO}_{4}$ as eluent).

\section{Viability}

Live cell percentage was determined by two methods. The first one was the staining of cells with Acridine orange/Propidium iodide (AO/PI) solution ( $1 \mathrm{~g} / \mathrm{L} \mathrm{AO}$ and $0.07 \mathrm{~g} / \mathrm{L}$ PI in PBS). Therefore, the cell suspension was diluted with PBS to obtain a cell density of approximately $5 \cdot 10^{8}$ cells $/ \mathrm{mL}$. A $1: 1$ mixture of cell suspension and AO/PI stain solution was incubated at room temperature for $2 \mathrm{~min}$. The stained cells are then pelleted by centrifugation at 14,000 $\mathrm{g}$ for $2 \mathrm{~min}$. The pelleted cells are resuspended in PBS and centrifuged again. Finally, resuspended cells were analyzed via fluorescence microscopy. Viable cells appear green and dead cells red when excited with blue and green light, respectively.

The second method was the determination of colony forming units (CFU) by plating out a dilution series of cell suspension on MRS agar plates. The difference between cell density of the cell suspension determined by measuring the $\mathrm{OD}$ and the CFU gives the amount of dead cells in the suspension.

\section{Calculations for the Fixed-bed Reactor}

The volume specific biomass productivity of the fixed-bed reactor $\mathrm{q}_{\mathrm{x}}{ }^{\mathrm{N}}$ was calculated from

$$
q_{X}^{*}=X_{\text {out }} \cdot D \quad \text { [cells/[ L.h )] }
$$

with $\mathrm{X}_{\text {out }}$ as suspended cell concentration in the harvest stream in [cells/L] and dilution rate $\mathrm{D}[1 / \mathrm{h}]$. The latter is the ratio of fluid flow $[\mathrm{L} / \mathrm{h}]$ and fixed-bed volume $[\mathrm{L}]$.

The volume specific lactate productivity $\mathrm{q}_{\mathrm{Lac}}^{*}$ was calculated from

$$
q_{\text {Lac }}^{*}=\left(c_{\text {Lac out }}-\quad{ }_{\text {Lac }, \text { in }}\right) \cdot D \quad[\mathrm{~g} /(\mathrm{L} . \mathrm{h})]
$$

with the lactate concentration in the feed $\mathrm{c}_{\mathrm{Lac}, \text { in. }}$ and in the harvest $\mathrm{c}_{\mathrm{Lac}, \text { out. }}$. The concentration of immobilized cells $\mathrm{X}_{\mathrm{FB}, \text { est }}$ was estimated as

$$
X_{F B \text { est }}=\frac{q_{\text {Lac }}^{*}}{q_{\text {Lac,batch }}} \quad[\text { cells } / \mathrm{L}]
$$

with the cell specific lactate productivity in batch suspension culture $\mathrm{q}_{\text {Lac,batch. }}$.

\section{RESULTS AND DISCUSSION}

One of the major characteristics of fixed-bed reactor systems is the simple design and the low complexity. In contrast to stirred suspension reactors, which are considered to be homogeneously mixed, fixed-bed reactors have gradients along the height for all parameters like concentrations of biomass, substrate and product. Also the $\mathrm{pH}$ value shifts as it is not controlled in these systems.

The dilution rate is an important parameter for every kind of continuous cultivations because it is correlated with the volumetric productivity. Especially for fixed-bed cultivations with their simple design and low complexity, the dilution rate is the only parameter to be varied during a running cultivation.

\section{Impact of Dilution Rate and Consistency of Experiments}

To investigate the impact of dilution rate on cell growth and activity within the fixed-bed, and the consistency (reproducibility) of experiments, two set-ups were run with six fixed-bed units each time. The dilution rate was increased stepwise from $0.67 \cdot \mu_{\max }$ to $1.2 \cdot \mu_{\max }$, corresponding to values of $\mathrm{D}=0.261 / \mathrm{h}$ to $0.471 / \mathrm{h}$. In particular dilution rates similar or higher as the maximum growth rate are important to judge the stability of the fixed-bed, as for 
continuous chemostat cultures with suspended cells washout of cells occurs at these high dilution rates. In total, the Multiferm was run for $154 \mathrm{~h}$ in this experiment.

An example for the time course of colonization of the carriers within the fixed-bed units is shown in Fig. (4). Especially between $120 \mathrm{~h}$ and $154 \mathrm{~h}$ of process time the formation of the biofilm increased drastically. At $\mathrm{t}=154 \mathrm{~h}$ the carriers are completely covered with cells. At this point in time the dilution rate was already $\mathrm{D}=1.2 \cdot \mu_{\max }$. As no washout of cells occurred, the stability of the fixed-bed system is confirmed.

The time course of cell $\left(\mathrm{X}_{\text {out }}\right)$ and lactate concentration and $\mathrm{pH}$ at the outlet of the fixed-bed units (harvest flow) as well as the volume specific productivities $\left(\mathrm{q}^{*}\right)$ are given in Fig. (5).

For perfusion of each fixed-bed unit fresh MRS medium with a pH of 6 was used. The activity of the immobilized cells led to a $\mathrm{pH}$ shift to 4.6 at the outlet already at the first sampling at $9.5 \mathrm{~h}$ of fermentation. From that on $\mathrm{pH}$ was constant in the following course of cultivation.

The system shows a good stability since the $\mathrm{pH}$ at the outlet and the volumetric specific lactate productivity $\mathrm{q}_{\text {Lac }}^{*}$ was nearly constant throughout the cultivation. The reproducibility of the system between different experiments and between different fixed-bed units is good since the standard deviation is $13 \%$ at the most for all concentrations and productivities. Furthermore, it can be seen that at higher dilution rates the cell concentration in the outlet rises up to $3.5 \cdot 10^{8}$ cells $/ \mathrm{mL}$ and the lactate concentration decreases at the most from $5.7 \mathrm{~g} / \mathrm{L}$ to $3.3 \mathrm{~g} / \mathrm{L}$ due to dilution effects.

It seems that the higher dilution rates of $\mathrm{D}=\mu_{\max }$ to $\mathrm{D}=1.2 \cdot \mu_{\max }$ lead to a better supply of the cells because more cells are in the outlet whilst the lactate productivity is stable at $1.4 \mathrm{~g} /(\mathrm{L} . \mathrm{h})$.

\section{Long-term Cultivation}

In the before mentioned experiment the dilution rate was increased stepwise in relatively short time intervals. In the following an experiment is described, where the dilution rate was fixed to $\mathrm{D}=\mu_{\max }$ during a period of $300 \mathrm{~h}$ (Fig. 6). Two fixed-bed units were run in parallel.

All determined parameters reached constant values after approx. $150 \mathrm{~h}$. Therefore, this experiment underlines the long-term stability of the fixed-bed system even at high dilution rates.

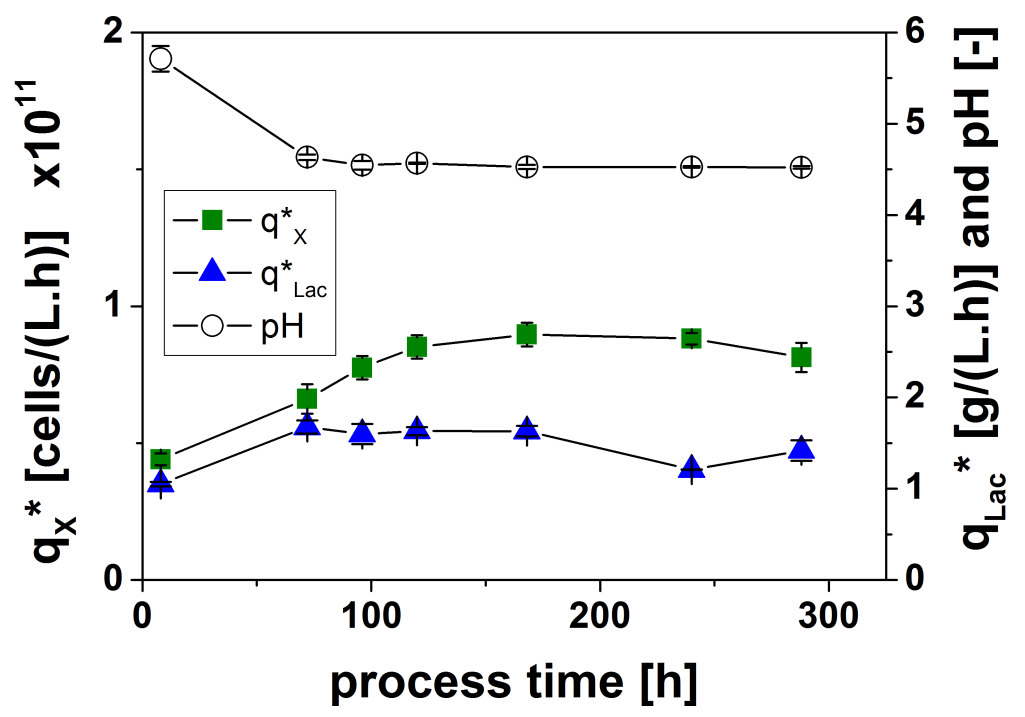

Fig. (6). Cultivation of L. bulgaricus in Multiferm system with constant dilution rate $\left(\mathrm{D}=0.391 / \mathrm{h}=\mu_{\max }\right)$. Conditions: MRS medium (intial $\mathrm{pH}$ of 6$), 40^{\circ} \mathrm{C}, 2$ fixed-bed units $(\mathrm{n}=2)$. Data points represent means \pm standard deviation.

Interestingly, the $\mathrm{pH}$ reaches again the final value of 4.6 only at the second sampling after $72 \mathrm{~h}$ of fermentation for unknown reasons.

The biomass in a fixed-bed reactor cannot be determined by sampling during the cultivation. An approach to 
estimate the number of immobilized cells is to assume a cell specific lactate production rate similar to the production rate in suspension. In that case the cell concentration can be calculated by dividing the volume specific lactate productivity (in g/(L.h)) by the cell specific lactate productivity from suspension culture (in g/(cell.h)) (see above). For the cultivations shown in Fig. (6), the estimated cell concentration $\mathrm{X}_{\mathrm{FB} \text {,est }}$ varied between 4 to $6 \cdot 10^{8}$ cells $/ \mathrm{mL}$, if $2.6 \cdot 10^{-12} \mathrm{~g} /\left(\right.$ cell.h) as cell specific lactate production rate $\mathrm{q}_{\mathrm{Lac}, \text { batch. }}$ from batch suspension cultivation was assumed.

At the end of this experiment the cells were detached from the carriers by ultrasonic sound (Bransonic bath 221, $15 \mathrm{~s}$ ), followed by vortexing for maximal $5 \mathrm{~s}$ to avoid abrasion of the carriers. The optical density of the received cell suspension was measured and gave $1.89 \cdot 10^{9}$ cells $/ \mathrm{mL}$ as real cell density in the fixed-bed. A viability test by plating the cell suspension on MRS agar plates resulted in a viability of $74 \%$, which is the same as for chemostat processes with L. bulgaricus under same conditions (MRS medium, $40^{\circ} \mathrm{C}$ ).

Assuming that no drastical shift in metabolism occurs, the difference of factor ten between estimated and real biomass in the fixed-bed under same viability could be a reduced growth rate.

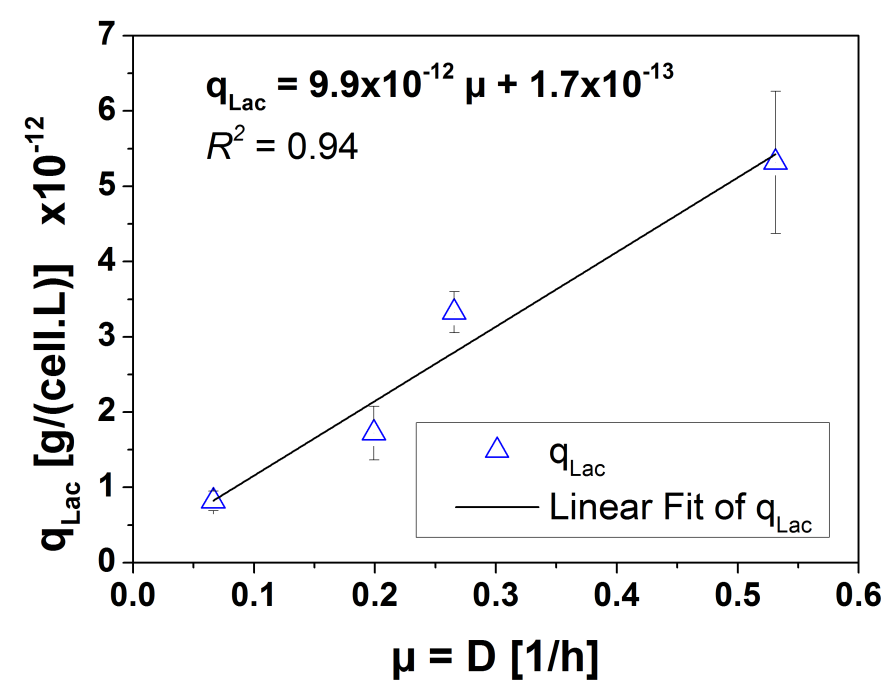

Fig. (7). Correlation between cells specific lactate productivity and specific growth rate during chemostat cultivation of $L$. bulgaricus. Conditions: MRS medium (intial $\mathrm{pH}$ of 6$), 40{ }^{\circ} \mathrm{C}, 500 \mathrm{~mL}$. Data points represent means \pm standard deviation $(\mathrm{n}=2-10$ per dilution rate).

\section{Influence of Immobilization on Growth Rate}

The results of the long-term cultivation in the previous section gave first indications that L. bulgaricus cells change the growth rate in immobilized state. The detachment of cells at the end of the long-term cultivation showed that the real biomass is approximately one magnitude higher than the calculated one. The estimation is based on the cell specific lactate productivity of cells cultivated in suspension. Chemostat cultivation of L. bulgaricus under same conditions regarding temperature, $\mathrm{pH}$ and medium (see Fig. 7) showed a linear correlation between growth rate of cells and the cell specific lactate productivity to be:

$$
q_{\text {Lac }}=9.9 \cdot 10^{-12} \cdot \mu+1.7 \cdot 10^{-13} \quad[\mathrm{~g} /(\text { cell.h })]
$$

Since the real cell density $\mathrm{X}_{\mathrm{FB} \text {,real }}$ at the end of the long-term cultivation is known to be $1.89 \cdot 10^{9} \mathrm{cells} / \mathrm{mL}$ and the average volume specific lactate productivity $\mathrm{q}_{\mathrm{Lac}}^{*}$ is $1.5 \mathrm{~g} /(\mathrm{L} . \mathrm{h})$, the cell specific lactate productivity $\mathrm{q}_{\mathrm{Lac}}$. can be calculated to be $0.79 \cdot 10^{-12} \mathrm{~g} /($ cell.h) for immobilized cells. By this, the correlation between cell specific lactate productivity and specific growth rate results in a specific growth rate of $\mu_{\mathrm{FB}}=0.0631 / \mathrm{h}$ for immobilized cells. This value is nearly one magnitude lower than the growth rate of free suspended cells.

Preliminary experiments in batch cultivation with suspended cells showed that the influence of a $\mathrm{pH}$ shift on 
maximum specific growth rate is negligible in the $\mathrm{pH}$ range from 4.6 to 6 (data not published). Therefore, the reason for the lower $\mu_{\mathrm{FB}}$ could be diffusion limitations within the biofilm.

\section{CONCLUSION}

As described in the materials and methods section, the Multiferm has twelve single fixed-bed units that can be operated independently. Consequently, experiments can be performed simultaneously either with one times twelve, two times six or four times three fixed-beds with different options to accelerate the development of fixed-bed processes with immobilized cells. One option is to perfuse the units with different media, cultivating one strain in each for medium testing. Determination of the above mentioned productivities for biomass and product can also be carried out to find the best strain in a certain medium in case of mutant screening. Moreover, the influence of different dilution rates or carriers on the performance of fixed-bed cultivations can be investigated. For a better understanding of fixed-bed processes in general, the increase of immobilized biomass and the formation of biofilms can be studied by time course experiments. If this is done during the start-up process at certain time intervals before reaching constant productivity values, kinetic parameters could be used to create a model for fixed-bed processes. Especially for these kinetic studies, the Multiferm is superior to single experiments where growth related parameters change from one experiment to another. In case of aerobic strains, a conditioning vessel can be integrated to dissolve oxygen up to total saturation for sufficient oxygen supply of the cells. The downscaled design of the Multiferm leads to a cost-efficient process development. In this context, the enormous time reduction has to be mentioned. Regarding the first experiment described here, the cultivation could be reduced to $308 \mathrm{~h}$ in total compared to approximately $2000 \mathrm{~h}$ in single fixed-bed systems.

The Multiferm was successfully used for cultivation of immobilized Lactobacillus delbrueckii ssp. bulgaricus. Cultivations were reproducible and the generation of a relevant amount of data was fast and easy in this multiple reactor system. The investigation of the biomass within the fixed-bed indicated a change in growth rate of immobilized cells as also reported in literature for other immobilized LAB $[3,5]$.

The usage of a conditioning vessel would also allow the cultivation of aerobic mammalian or bacterial cells. Thus, the Multiferm can be used as a powerful tool for bioprocess development of fixed-bed processes.

\section{CONFLICT OF INTEREST}

The authors confirm that this article content has no conflict of interest.

\section{ACKNOWLEDGEMENTS}

The financial support from Federal Ministry of Education and Research (BMBF) under grant No. 0.31A124A ("ProTool 2") is gratefully acknowledged as well as the work of the project partners (GALAB Laboratories GmbH, Ingenieurbüro Schoop, medorex e.K. and Prof. Dr.-Ing. Hass from Hochschule Furtwangen). The project is part of the BIOKATALYSE2021 cluster.

The Lactobacillus strain was kindly donated by Prof. Dr. Detlef Goelling from OrganoBalance (Berlin, Germany).

\section{REFERENCES}

[1] Tango MS, Ghaly AE. A continuous lactic acid production system using an immobilized packed bed of Lactobacillus helveticus. Appl Microbiol Biotechnol 2002; 58(6): 712-20. [http://dx.doi.org/10.1007/s00253-002-0970-3] [PMID: 12021789]

[2] Lacroix C, Yildirim S. Fermentation technologies for the production of probiotics with high viability and functionality. Curr Opin Biotechnol 2007; 18(2): 176-83.

[http://dx.doi.org/10.1016/j.copbio.2007.02.002] [PMID: 17336510]

[3] Lacroix C, Grattepanche F, Doleyres Y, Bergmaier D. Immobilised cell technologies for the dairy Industry applications of cell immobili biotech. Springer: Netherlands 2005; pp. 295-319.

[http://dx.doi.org/10.1007/1-4020-3363-X_18]

[4] Pörtner R, Märkl H. Festbettreaktoren für die Kultur tierischer Zellen. Bioforum 1995; 18: 449-52.

[5] Dagher SF, Ragout AL, Siñeriz F, Bruno-Bárcena JM. Cell immobilization for production of lactic acid biofilms do it naturally. Adv Appl Microbiol 2010; 71: 113-48. [http://dx.doi.org/10.1016/S0065-2164(10)71005-4] [PMID: 20378053]

[6] Pörtner R, Seemuk M, Schlothauer RC, Elsser D. Anaerobe Kultivierung von Lactococcus lactis im Festbettreaktor. Chemieingenieurtechnik (Weinh) 2004; 76: 1599-602. 
[http://dx.doi.org/10.1002/cite.200407012]

[7] Roble ND, Ogbonna JC, Tanaka H. L-Lactic acid production from raw cassava starch in a circulating loop bioreactor with cells immobilized in loofa (Luffa cylindrica). Biotechnol Lett 2003; 25(13): 1093-8. [http://dx.doi.org/10.1023/A:1024192131343] [PMID: 12889820]

[8] Doleyres Y, Fliss I, Lacroix C. Continuous production of mixed lactic starters containing probiotics using immobilized cell technology. Biotechnol Prog 2004; 20(1): 145-50. [http://dx.doi.org/10.1021/bp020096w] [PMID: 14763837]

[9] Chantawongvuti R, Veerajetbodithat J, Jaturapiree P, Muangnapoh C. Immobilization of Lactobacillus salivarius ATCC 11741 on loofa sponge coated with chitosan for lactic acid fermentation. J Microbiol Biotechnol 2010; 20(1): 110-6. [PMID: 20134241]

[10] Lamboley L, Lacroix C, Artignan JM, Champagne CP, Vuillemard JC. Long-term mechanical and biological stability of an immobilized cell reactor for continuous mixed-strain mesophilic lactic starter production in whey permeate. Biotechnol Prog 1999; 15(4): 646-54. [http://dx.doi.org/10.1021/bp990063p] [PMID: 10441356]

[11] Vijayakumar J, Aravindan R, Viruthagiri T. Recent trends in the production, purification and application of lactic acid. Chem Biochem Eng Q 2008; 22(2): 245-64.

[12] Taskila S, Ojamo H. The current status and future expectations in industrial production of lactic acid by lactic acid bacteria. In: Lactic Acid Bacteria - R \& D for Food, Health and Livestock Purposes. InTech 2013. Available from: http://www.intechopen.com/books/ lactic-acidbacteria-r-d-for-food-health-and-livestock-purposes/the-current-status -and-future-expectations-in-industrial -production-of-lactic-acid-bylactic-acid-ba.

[13] Champagne CP, Lacroix C, Sodini-Gallot I. Immobilized cell technologies for the dairy industry. Crit Rev Biotechnol 1994; 14(2): 109-34 [http://dx.doi.org/10.3109/07388559409086964] [PMID: 8069933]

[14] Pörtner R, Faschian R, Goelling D. Fermentation of lactic acid bacteria: State of the art and New perspectives Applied biocatalysis: From fundamental science to industrial applications. Germany: Wiley-VCH 2015.

\footnotetext{
Received: May 21, 2015

Revised: August 14, 2015

Accepted: November 12, 2015

(C) Faschian et al.; Licensee Bentham Open.

This is an open access article licensed under the terms of the Creative Commons Attribution-Non-Commercial 4.0 International Public License (CC BY-NC 4.0) (https://creativecommons.org/licenses/by-nc/4.0/legalcode), which permits unrestricted, non-commercial use, distribution and reproduction in any medium, provided the work is properly cited.
} 